\title{
Quality Assurance among Childcare Employees in Selangor
}

\author{
YATY SULAIMAN*, NG KEL LIE \\ School of Business Management, College of Business \\ Universiti Utara Malaysia, Kedah \\ MALAYSIA
}

\begin{abstract}
Caregiver or childcare employee is responsible to produce excellent quality in taking care of the children. A good practice of quality assurance among employees is important to develop the future generations. The objective of this research is to identify the factors that influence quality assurance among childcare employees in Selangor. It is to determine the relationship between factors (physical facilities, employee commitment, communication, and employee competencies) and quality assurance. A random sampling technique was used to select respondents from the registered childcare centers in Selangor, Malaysia. The study used quantitative approach through structured questionnaires developed from previous research. Among 450 survey questionnaires distributed, only 379 questionnaires were accepted and used for analysis. Study uses SPSS 22.0 to analyze data. Methodologies such as Pearson Correlation and Multiple Regression Analysis were conducted in analyzing the data. Findings revealed that quality assurance is having a positive relationship with physical facilities, employee commitment, communication, and employee competencies, with the overall results of the multiple regression analysis showed that all independent variables have relationships with the dependent variable at $\mathrm{p}=0.000$. The result of this test also indicated that all independent variables have positive beta coefficient value as physical facilities, employee commitment, communication and employee competencies at $0.372,0.251,0.064$ and 0.103 respectively. Thus, this study adds to better understanding of the total quality management (TQM) which is the main underlying theory used to develop the research framework. In general, Total Quality Management (TQM) advised on the factors such as physical facilities, employee commitment, employee competencies, and communication that when applied, could get the best result of employees.
\end{abstract}

Keywords:- Quality assurance, childcare employee, employee competencies, employee commitment and communication

Received: March 12, 2021. Revised: November 6, 2021. Accepted: November 17, 2021. Published: December 2, 2021.

\section{Introduction}

As for today, childcare centres in Malaysia has been growing drastically. Ministry of Woman, Family and Community mentioned that the number of childcare centres from the year 2007 to 2016 has increased from 2176 to 4272 respectively (Heng Keng Chiam, 2008; JKM, 2018). This is because "registered centres in the country were found to be insufficient to meet the demand to place children" said by Datuk Seri Rohani Abdul Karim [1]. On the other hand, the number of women entrepreneurs increased by years due to the support of government and organizations. According to [2] woman entrepreneurship can be strengthen by having childcare subsidies for childcare service in Malaysia. In the meantime, it does contribute to the country economic as the growing number of the childcare centres with the support of government. The government does offer education course to standardize the education of the childcare centres such as PERMATA nursing course and so on.

In addition, based on the government policies, more Malaysian women earn higher wages and assume key decision-making positions. This can be explained by the government has been pressing for childcare centres at workplaces to help Malaysia achieve its goal of women accounting for 59 per cent of the workforce, with new 226 childcare centres in public and private centres respectively [1]. Although childcare centres are increasing from years to years, however, there are issues caused dreadful incidents like negligence to the extent of causing injury, death, sexual abuse and more towards children at the centres, low wages, and so on. Besides that legal childcare centres had are overburdened of children by the ratio of 1:20, said by Association of Registered Childcare Providers 
Malaysia (ARCPM) president P. H. Wong. Legal law in Malaysia, mentioned that there are no specific labour laws to ensure employers to provide childcare centres or nursery for working mothers does not exist. This is important to provide a childcare centre at workplace so that the working mother can focus to their work as the safety of childcare centre secured by the company [37] [38] [40].

\section{Literature Review}

\subsection{Quality Assurance}

In Malaysia, mostly of all the quality assurance researches are focusing in halal food. For instance, research regarding quality assurance in halal food manufacturing in Malaysia. Quality assurance is important for childcare industry as it aimed to provide and improve the quality level of the childcare so that it can produce better quality standards for the children in childcare centre [42]. Therefore, the literature in this study intend to close the gap between quality assurance and childcare. In general, quality assurance varies depend on the field of the researcher study. The quality assurance of childcare in Malaysia is very limited and there is no measurement available such as QIAS or Infant Environment Rating Scale were built to test or measure the quality in Malaysia [43]. Therefore, the literature of quality assurance gives a sight on quality assurance in childcare, other industry such as education, software, medical and evolution studies of quality assurance in Malaysia. According to [3], quality assurance defined as the whole process to provide excellent quality which requirement and standard needed such as guarantees product, service or institution to meet the quality level. Besides, referring to [4], quality assurance is defined as specific measure that reflect required input and outcome. Quality perspectives which includes encouragement by the organization in giving priority to quality practices is important to develop quality culture [5].

\subsection{Physical Facilities}

A conducive environment emphasizes cooperation and openness between two parties [6]. In general, there are no specific terms for physical facilities. Physical positioning at the right place and with right time is extremely vital [7]. It was defined vary according to its dimensions and industry. On the other hand, referring to law insider, physical facilities defined as buildings and physical structure that constructed by contractor. Environmental consciousness also reflects to every action which are significant to environment and the use of environmental resources [8]. Besides, in term of education perspective, physical facilities also known as physical plant which consists of land, building, furniture and so on [9]. From the other point of view, physical facilities are used to measure the neighborhood environment and physical activity. For example, study from [10] examine the comparison of public and private recreational facilities among youth to test the environment and physical activity level. The findings showed that people tend to use public facilities than private thus importance of public facilities for the youth. Physical facilities are important to ensure the functioning of services [11] [41].

\subsection{Employee Commitment}

Behavior is a person action and attitude when they engage in an activity [12]. Employee commitment have been defined in various research literature. For example, employee commitment is defined as the strength of individual recognition and participation in specific organization [13]. Besides, commitment also being defined as connections towards goal [14], attitude to works [15] which explained employee commitment in different forms to influence behavior. In addition, there are other research that linked with commitment such as employee commitment and well-being. According to [16], three component commitment were used to test the relationship between employee commitment and well-being. In addition, recent study from [17] pointed out that there are relationship between employee loyalty and organizational commitment. There are studies on organizational effectiveness linking with employee commitment. The result proven that there is significant relationship between employee commitment and organization effectiveness through employer and employee relationship. When an employee's wants and needs are generated with the benefits, individual reward systems, performance reviews, training, and flexible physical setting by the manager, in return, it will create higher level of job satisfaction among their employees [18] [39]. Apart from this, most of the organization in Malaysia are urged to engage with technology advancement [19].

\subsection{Communication}

Communication is important as it deliver information and knowledge among people. For instance, communication is important for an organization to perform and successful. The following section will discuss definitions of 
communications, studies on communication and interrelation between communication and quality assurance. According to [20], communication is defined as process for replicate memories to conduct attention for other people. In addition, research from [21] implies that good communication is the important element for an organization to be successful. It might lead to employee commitment and many other benefits.

\subsection{Employee Competencies}

Competencies can be the element of competitive advantage for organizations to perform and successful [22]. The concept of competencies viewed differently across the organization. For instance, research on psychologists, management theorists, human resource, educationists and so on. The following section will be explaining the definition, past studies and relation of employee competencies and quality assurance [39]. According to [22], competencies defined as characteristics associated with successful performance. Besides, [23] define competencies as ability in person and predict performance [24]. In addition, [25] refer "competence consists of four element such as technology, people, organizational culture and structure" and lead to competencies from easy to hard. Moreover, [26] defined competency in two meaning which is output and input. Output referring to competent performance while input is the underlying attributes.

\subsection{Theoretical Framework}

The theoretical framework of this study is shown in Fig. 1. Quality assurance is the main variable which required to be investigated in this study. There are four independent variables which are physical facilities, employee commitment, employee competencies and communication.

Independent Variable (IV)

Dependent Variable (DV)

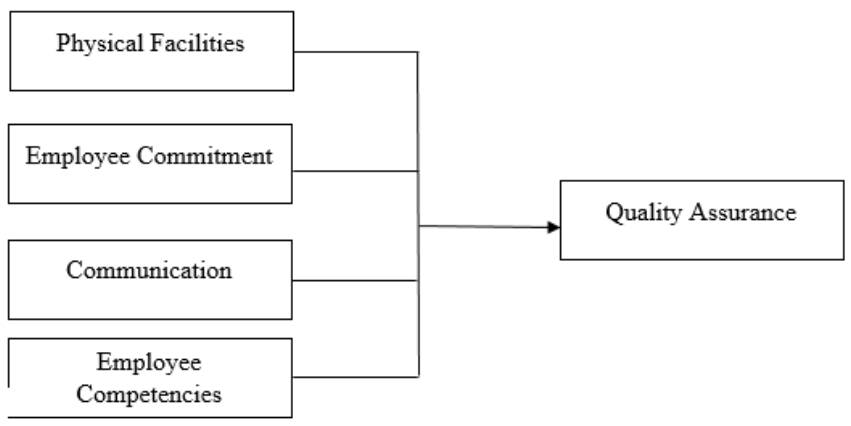

Fig. 1: Theoretical Framework of the Research

\subsection{Hypotheses Development}

H1: There is a significant relationship between Physical Facilities and Quality Assurance among childcare employees in Selangor.

$\mathrm{H} 2$ : There is a significant relationship between Employee Commitment and Quality Assurance among childcare employees in Selangor.

H3: There is a significant relationship between Communication and Quality Assurance among childcare employees in Selangor.

H4: There is a significant relationship between Employee Competencies and Quality Assurance among childcare employees in Selangor.

\section{Research Methodology}

\subsection{Research Design}

Study concluded that a quantitative method is suitable for this study by using questionnaires to collect a data. Survey methods are mostly used to collect descriptive data in quantitative research. A quantitative research helps researchers to gain information and obtain greater understanding of the relationship among the variable, level of significance of hypothesis. Data were analyzed using "Statistical Package for Social Science" (SPSS) version 22.0. This study is using a survey form questionnaire to collect primary data. Likert scales are used to measure the response of the respondents. Likert scale from 1 to 5 which ranging from "1-Strongly Disagree" to "5-Strongly Agree" is applied for measurement. The five-point scale is appropriate as it keep the comparability of the result. In order to test the reliability of the item, pilot test has been carried out. The questionnaire was prepared in dual language which is English and Malay to ensure the respondent can understand and fill in accordingly.

\subsection{Population and Sampling}

The populations of this study are the childcare employees in registered childcare centres of Selangor state. According to Ministry of Women, Family and Community Development (2016), the population of childcare centres in Malaysia is 4272 . For this study, there are total of 1360 childcare centres in Selangor. Based on the number of childcare centre, each centre was assumed to have at least three childcare employees. Therefore, there are estimated around 4080 childcare employees at Selangor. This study focuses on all the registered childcare in Selangor as the study population and a sample. This study used simple random sampling as 
the sampling techniques where childcare centres are randomly selected to conduct the survey. The reason for selecting registered childcare because all the childcare employee performs the same responsibility regardless where they are and this indicate that the selected sample can achieve generalizability to represent the registered childcare centres population.

\subsubsection{Sample Size Determination}

Based [27], there is seldom justification for sample of this study which more than 30 but less than 500 as is suitable for most of the research. In order to determine the sample size, [28] produced a table by applying the formula of sample size for a finite population. Based on the table, with the population of 4080 , the sample size is 354 . Therefore, there are around 450 sets of the questionnaire will be distributed to childcare centres in Selangor.

The table for the sample size determination recommended by [28] is shown as below:

Table 1. Table for deciding Sample Size of a Known Population

\begin{tabular}{cc}
\hline Population Size & Number of samples \\
\hline 4000 & 351 \\
4500 & 354 \\
5000 & 357 \\
\hline
\end{tabular}

Source: Krejcie and Morgan (1970)

\subsubsection{Sampling Design}

This study adopted convenience sampling techniques. Convenience sampling is one of nonprobability sampling method where the respondent is convenient to respond in the study. This sampling techniques has been used and applied in the study and conducted in the childcare centres in Selangor. This technique is suitable it is simple, ease of research, helpful for data collect for the study (Convenience sampling - Research Methodology).

\subsubsection{Unit of Analysis}

Based on the population, the unit analysis is the childcare employees in childcare centres. This study is focus on the individual employees of registered childcare centres. Therefore, the data will be collected from everyone.

\subsection{Questionnaire Design}

In this study, questionnaire is developed to obtain information from respondents comprises of 35 questions. The questionnaire is divided into 2 sections. Section A is to require demographic data of respondents. Section B covers question which related to dependent and independent variables of the study. Section A and section B has 6 and 29 questions respectively. In Section A, it consists the information of gender, age, ethnic group, religion, highest education level, as well as working experience. Section $B$ aims to collect the information from respondents regarding Quality Assurance, physical facilities, employee commitment, employee competencies and communication.

\subsection{Measurement of Study}

Likert scales measurement are used to measure all the questions in Section B as it can generate data that valid and reliable. Respondents are required to indicate a response to each statement according to the stated scale.

Table 2 below shows the measurement scales and score used in this study:

Table 2. Measurement Scales

\begin{tabular}{ll}
\hline \multicolumn{1}{c}{ Scales } & Score \\
\hline Strongly Disagree & 1 \\
Disagree & 2 \\
Neutral & 3 \\
Agree & 4 \\
Strongly Agree & 5 \\
\hline
\end{tabular}

Source: McLeod (2008)

\subsection{Data Collection Method}

Primary data were collected through questionnaires survey method. The researcher conducted personally administered questionnaires to obtain immediate reply from respondents and can explain to respondent in the same time if they don't understand. Registered childcare centres in Selangor has been selected as respondents in this study. The population of the registered childcare centres in Selangor is 1360. The sample size for 4080 population is 354 childcare employees in childcare centre as respondents. In this study, 450 questionnaires were distributed to all of the respondents by using simple random sampling method. The questionnaire took around 30 minutes to be completed. A total of 450 questionnaires were distributed and 400 questionnaires were returned. However, 21 questionnaires were rejected due to incomplete and therefore 379 questionnaires remained and were used for analysis.

\subsection{Pilot Test}

The research questions and hypothesis of this study measures five main variables, quality assurance, physical facilities, employee commitment, employee 
competencies and communication. Each of the variable was measured by a list of questions item using a Likert type scale. A pilot test was performed among the registered childcare centres employee in Selangor. Thirty number of childcare employees among the registered childcare centre were selected to participate in the pilot test. The pilot test aims to ensure every respondent understand the question in the questionnaire. The pilot test can assist to improve the questionnaire development and pretesting before implementing in bigger scale. The result of pilot test showed in Table 3 below.

Table 3. The Cronbach Alpha for Pilot Test

\begin{tabular}{ll}
\hline Variables & Pilot Test $(\mathbf{n}=\mathbf{3 0})$ \\
\hline Quality Assurance & 0.887 \\
Physical Facilities & 0.816 \\
Employee Commitment & 0.852 \\
Communication & 0.874 \\
Employee Competencies & 0.874 \\
\hline
\end{tabular}

\subsection{Data Analysis Strategy}

The current study used quality assurance as the dependent variable, while physical facilities, employee commitment, employee competencies and communication as independent variable. Statistical Package for Social Science (SPSS version 22.0) software were used to analyze questionnaire data. Next, normality test is applied to examine whether the data is in normal distribution. Besides, reliability test is used to measure the validity. Not only this, descriptive analysis is used to measure the individual demographic characteristics.

\subsection{Reliability Test}

In this research, researcher intended to do interitem consistency reliability to measure the answer of all item whether correlated with each other. Hence, Cronbach's alpha is used to test the items. If the Cronbach's Alpha value is greater than 0.7, the internal consistency is acceptable.

\section{Table 4. Internal Consistency Measurement}

\begin{tabular}{ll}
\hline Cronbach's Alpha & Internal Consistency \\
\hline $0.9=\alpha$ & Excellent \\
$0.8=\alpha<0.9$ & Good \\
$0.7=\alpha<0.8$ & Acceptable \\
$0.6=\alpha<0.7$ & Questionable \\
$0.5=\alpha<0.6$ & Poor \\
$\alpha<0.5$ & Unacceptable \\
\hline
\end{tabular}

Source: Sekaran \& Bougie (2016)

\subsection{Validity Test}

In this study, researcher used face validity and construct validity. Face validity used the items to measure the concept while construct validity used the result measurement fit with the theories. One of the reason validity test used to measure the factor analysis, using multivariate technique to examine the most appropriate item for each variable [29].

\subsection{Factor Analysis}

Factor analysis is used to summarize data into a small number of factors from larger number of variables. In addition, factor analysis also used to generate hypotheses such as collinearity analysis and linear regression analysis. Moreover, [30] stated that Kaiser-Meyer-Olkin (KMO) test is measure of sampling adequacy of variable which is suitable for factor analysis. For instance, one of the rules of thumb for KMO values between 0.8 and 1 implies that sampling is adequate.

Table 5. KMO value and Variance Level

\begin{tabular}{ll}
\hline KMO Value & Degree of Common Variance \\
\hline 0.00 to 0.49 & Unacceptable \\
0.50 to 0.59 & Miserable. \\
0.60 to 0.69 & Mediocre. \\
0.70 to 0.79 & Middling. \\
0.80 to 0.89 & Meritorious. \\
0.90 to 1.00 & Marvelous. \\
\hline
\end{tabular}

Source: Andale (2017)

\subsection{Missing Value}

According to [31], missing values can lead to inaccurate statistical analysis and interpretation of data. Missing value is important as it will impact the result of the study. Some example of missing value such as noncoverage, total nonresponse, and item nonresponse [32].

\subsubsection{Normality Test}

Normality test is needed to be checked for many statistical process and procedure as the validity depends on it. Normality can be view in significance test and normal plot [33]. In this study, QuantileQuantile probability plot (Q-Q plot) has been used to test the normality. If the points located close to reference line in Q-Q plot, it is considered a standard normal distribution.

\subsection{Inferential Analysis}

According to [29], inferential analysis is the relationship between different group and inference from statistical results through sample to population. 
It consists of correlation, t-test, ANOVA, multiple regression analysis and so on.

\subsubsection{Pearson's Correlation Analysis}

Pearson's correlation analysis measures the relationship between two variables. In addition, it will provide result, strength and significance of bivariate relationship [29].

In fact, the symbol of correlation coefficients named as ' $r$ ' and the sign ranged from +1 to -1 . Value of +1 shows positive relationship while -1 show negative relationship.

Table 6. Strength of Pearson Correlation Coefficient

\begin{tabular}{ll}
\hline Range of Coefficient & Description of Strength \\
\hline \pm .70 or higher & Very Strong \\
\pm .40 to \pm .69 & Strong \\
\pm .30 to \pm .39 & Moderate \\
\pm .20 to \pm .29 & Weak \\
\pm .01 to \pm .19 & No or negligible \\
0 & Zero correlation \\
\hline
\end{tabular}

Source: Andale (2012)

\subsubsection{Multiple Regression Analysis}

Multiple regression analysis provides the most significant factors that influenced the quality assurance among childcare employees.

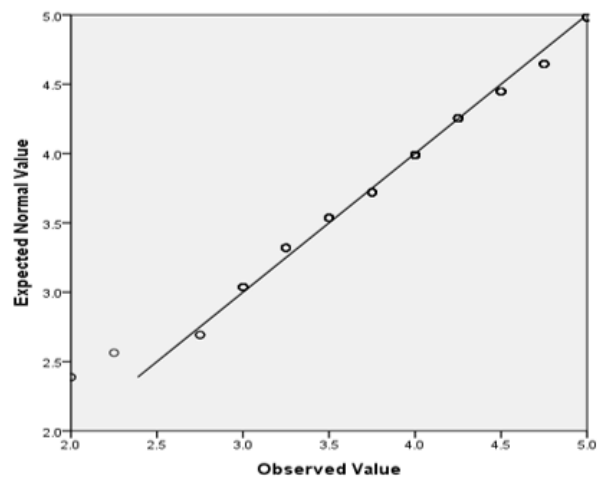

Fig. 2: Normal Q-Q plot of Quality Assurance

\section{Findings}

\subsection{Rate of Reaction of Respondents}

A total of 450 questionnaires were distributed to childcare employee in Selangor and 379 questionnaires were returned indicate the response rate for this study was $84.2 \%$. According to [34], it is favorable to get a high response rate around $80 \%$ and above from a small sample rather than large respondent and internal survey will normally generate $30-40 \%$ response rate. In this study, employee considered as internal survey and the response rate was $84.2 \%$. The distribution and collection of the completed questionnaires took around one month within January 2018. Table 7 shows the response rate.

Table 7. Total Rate of Reaction of Respondents

\begin{tabular}{ll}
\hline \multicolumn{1}{c}{ Items } & Respondent \\
\hline The number of questionnaires distributed & 450 \\
The number of questionnaires received & 400 \\
Complete questionnaire & 379 \\
Incomplete questionnaire & 21 \\
Rate of reaction received & $84.2 \%$ \\
\hline
\end{tabular}

\subsection{Reliability Test}

According to [29], if the alpha value is equal or greater than 0.7 is at acceptable level. While less than 0.7 is considered at weak and poor level. Reliability test result for pilot test and real test are shown in Table 8 below.

Table 8. Reliability Test result for Pilot Test and Real Test

\begin{tabular}{llll}
\hline Variable & No. Item & \multicolumn{2}{l}{ Cronbach's Alpha } \\
\hline & & $\begin{array}{l}\text { Pilot Test } \\
\text { N=30 }\end{array}$ & $\begin{array}{l}\text { Real Test } \\
\text { N=379 }\end{array}$ \\
\hline Quality Assurance & 8 & 0.887 & 0.890 \\
Physical Facilities & 4 & 0.816 & 0.820 \\
Employee Commitment & 7 & 0.852 & 0.892 \\
Communication & 6 & 0.874 & 0.870 \\
Employee Competencies & 4 & 0.874 & 0.868 \\
\hline
\end{tabular}

The reliability result shows that the coefficient of reliability of the variables is 0.816 to 0.887 for pilot test and 0.820 to 0.892 for the real test. The overall coefficient of reliability for pilot test and real test are 0.945 and 0.956 respectively. According to [29], the measurement of the variable for both independent and dependent variable is achieved excellent because it reached the alpha value more than 0.7 and above.

\subsection{Screening Data}

According to [29], the data obtained through survey or questionnaire need to be edited such as handling blank response, categorization, entering data before continue to analysis. In this study, data screening is examined through analyze the general descriptive statistics such as frequency distribution to determine if any outlier data, normality and missing data found. In fact, the result of descriptive data shows that there are no data was missing from 379 survey questionnaires returned. 


\subsubsection{Missing Data}

In this study, there are no missing data for the 379 respondent based on the SPSS analysis. Hence, the data proceed for the other analysis.

\subsubsection{Normality Test}

In this research, Q-Q plot was used to measure the normality test. Normal distribution of Q-Q plot should be aligned or near situated with the reference line. Graph below show the Q-Q plot for the variables. All the variable are in normal distribution and aligned with diagonal line. This is supported by [35] mentioned that if both sets of quantiles show normal distribution, then the points will roughly forming a straight line.

The Fig. 3 to Fig. 6 showed the result of normality test. The Q-Q plot results show that all the data are observations illustrate a straight line behaviour and close to the diagonal line, therefore the data is considered to be normally distributed.

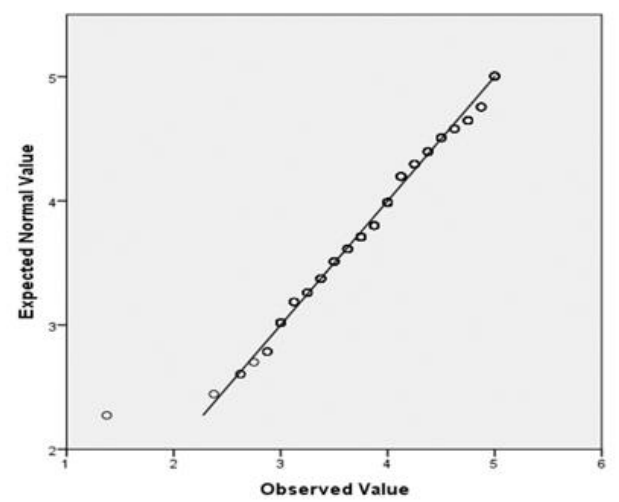

Fig. 3: Normal Q-Q plot of Physical Facilities

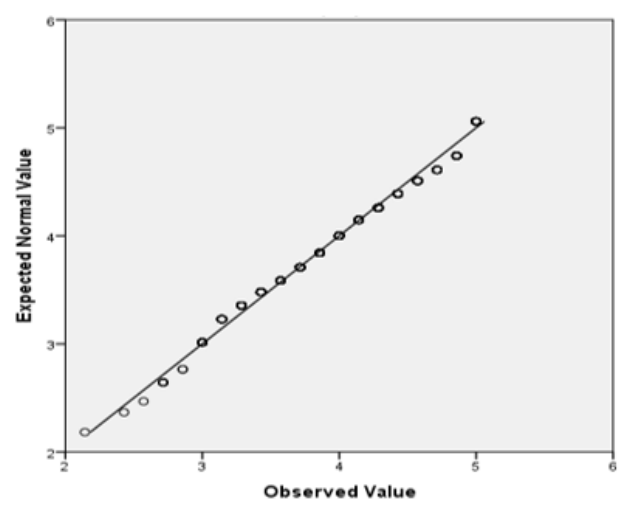

Fig. 4: Normal Q-Q plot of Employee Commitment

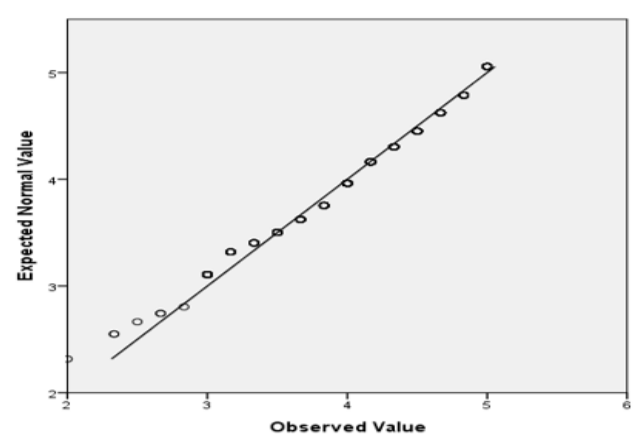

Fig. 5: Normal Q-Q plot of Communication

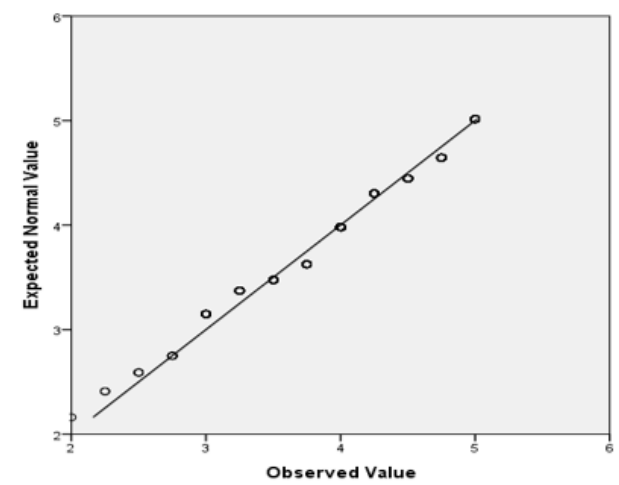

Fig. 6: Normal Q-Q plot of Employee Competencies

\subsection{Profile of the Respondents}

Tables below show the respondent profile through demographic analysis on respondents in this study.

Table 9. Gender of Respondents

\begin{tabular}{llll}
\hline Variable & Categories & Frequencies & Percent \\
\hline Gender & Male & 1 & 0.03 \\
& Female & 378 & 99.7 \\
Total & & 379 & \\
\hline
\end{tabular}

Table 9 above show the details of respondents gender that fill in the questionnaires. The first part of demographic detail is male and female. Respondent tick the answer that most describing themselves, 1 for male and 2 for female. Based on the total number of 379 respondent with $100 \%$, the results showed that mostly all the respondent were female which consists of 378 with $99.7 \%$ while there are only one male respondent with $0.3 \%$. This shows that in childcare industry mostly their employee were female. 
Table 10. Age of Respondent

\begin{tabular}{llll}
\hline Variable & Categories & Frequencies & Percent \\
\hline Age & $<25$ & 199 & 52.5 \\
& $25-35$ & 104 & 27.4 \\
& $36-45$ & 42 & 11.1 \\
& $46-55$ & 23 & 6.1 \\
& $>55$ & 11 & 2.9 \\
Total & & 379 & 100 \\
\hline
\end{tabular}

Table 10 showed the age detail for the respondent in the survey. The respondents age which is $<25$ have the highest frequency of 199 with $52.5 \%$. Next, the second highest were the age range of 25-35 respondent frequency of 104 with $27.4 \%$, followed by age range $36-45,46-55,>55$ with the frequency and percentage of $42(11.1 \%), 23(6.1 \%)$ and $11(2.9 \%)$ respectively.

Table 11. Ethnic of the Respondents

\begin{tabular}{llll}
\hline Variable & Categories & Frequencies & Percent \\
\hline Ethnic & Malay & 349 & 92.1 \\
& Chinese & 18 & 4.7 \\
& Indian & 11 & 2.9 \\
& Others & 1 & 0.3 \\
Total & & 379 & 100 \\
\hline
\end{tabular}

Table 11 above show the ethnic group for the respondents. The majority of the respondents were Malay with 349 respondents with 92.1\%. The second highest is Chinese ethnic group with the frequency of 18 and $4.7 \%$. The rest followed by Indian and other with amount of $11(2.9 \%)$ and one $(0.3 \%)$ respectively.

Table 12. Religion of the Respondents

\begin{tabular}{llll}
\hline Variable & Categories & Frequencies & Percent \\
\hline Religion & Muslim & 351 & 92.6 \\
& Buddhism & 12 & 3.2 \\
& Christianity & 8 & 2.1 \\
& Hinduism & 8 & 2.1 \\
Total & & 379 & 100 \\
\hline
\end{tabular}

Table 12 above showed the religion of the respondents such as Muslim, Buddhism, Christianity and Hinduism. Muslim achieved the highest frequency of 351 with $92.6 \%$. The second highest is Buddhism with the 12 respondent and $3.2 \%$. The rest followed by Christianity and Hinduism with the same frequency and percentage of eight and $2.1 \%$ respectively.
Table 13. Education level of the Respondents

\begin{tabular}{llll}
\hline Variable & Categories & Frequencies & Percent \\
\hline Education & PMR & 20 & 5.3 \\
& SPM & 178 & 47 \\
& STPM & 47 & 12.4 \\
& Others & 134 & 35.4 \\
Total & & 379 & 100 \\
\hline
\end{tabular}

Table 13 above showed the different education level for the respondents such as PMR, SPM, STPM and others. Table above showed the majority of the respondent were SPM holder with the frequency of 178 and $47 \%$. The second majority were the others categories which included diploma, certificate, degree holder. It consists of 134 of respondent with $35.4 \%$. The rest followed by STPM and PMR with the frequency and percentage of $47(12.4 \%)$ and 20 $(5.3 \%)$ respectively.

Table 14. Working Experience of the Respondents

\begin{tabular}{llll}
\hline Variable & Categories & Frequencies & Percent \\
\hline Working Experience & $0-5$ & 272 & 71.8 \\
& $6-10$ & 61 & 16.1 \\
& $11-15$ & 30 & 7.9 \\
& $>15$ & 16 & 4.2 \\
Total & & 379 & 100 \\
\hline
\end{tabular}

Table 14 above showed the years of working experience for respondent in the survey. Table above showed the majority of respondent were $0-5$ years of working experience with frequency of 272 and $71.8 \%$. The second majority were $6-10$ years with amount of 61 and $16.1 \%$. The rest followed by $11-15$ years and $>15$ with the amount of $30(7.9 \%)$ and $16(4.2 \%)$ respectively.

\subsection{Mean and Standard Deviation}

In this study, mean and standard deviation has been measured and used for the analysis. According to [29], mean is the average rate of central tendency while standard deviation estimate the dispersion for interval and ratio scaled data.

Table 15. Mean and Standard Deviation of Variables

\begin{tabular}{lll}
\hline \multicolumn{1}{c}{ Variable } & Mean & Standard Deviation \\
\hline Quality Assurance & 3.9446 & 0.57259 \\
Physical Facilities & 4.0864 & 0.62012 \\
Employee Commitment & 3.9812 & 0.61596 \\
Communication & 4.0708 & 0.60121 \\
Employee Competency & 4.0264 & 0.63903 \\
\hline
\end{tabular}


Table 15 showed the mean and standard deviations of all variables include dependent and independent variables for this study. The physical facilities variable has the highest mean value of 4.0864 while quality assurance variable has the lowest mean value which is 3.9446 .

\subsubsection{Mean and Standard Deviation of Quality Assurance}

Table 16 shows mean and standard deviation of dependent variable "Quality Assurance". The most dominant factor in measuring Quality Assurance value is the item "Quality related training technical given to employees throughout the childcare centre" and "Training in the total quality concept throughout the childcare centre", which have the equal mean value of 4.00 . Besides that, the item of "There is a comprehensiveness of goal-setting process for quality within the childcare centre", has the lowest mean value which is 3.87. Average of Quality Assurance has mean value of 3.9446 .

Table 16. Mean and Standard Deviation of Quality Assurance - Overall $(\mathrm{N}=379)$

\begin{tabular}{|c|c|c|}
\hline Items & Mean & $\begin{array}{l}\text { Standard } \\
\text { Deviation }\end{array}$ \\
\hline $\begin{array}{l}\text { There is a comprehensiveness of goal-setting process for } \\
\text { quality within the childcare centre. }\end{array}$ & or 3.87 & .729 \\
\hline $\begin{array}{l}\text { There is a degree of comprehensiveness of quality plan within } \\
\text { the childcare centre. }\end{array}$ & in 3.90 & .737 \\
\hline $\begin{array}{l}\text { Quality related training technical given to employees } \\
\text { throughout the childcare centre. }\end{array}$ & es 4.00 & .823 \\
\hline $\begin{array}{l}\text { Training in the total quality concept throughout the childcare } \\
\text { centre. }\end{array}$ & 4.00 & .807 \\
\hline $\begin{array}{l}\text { Availability of resources for employee training in childcare } \\
\text { centre. }\end{array}$ & 3.99 & .740 \\
\hline $\begin{array}{l}\text { Effectiveness of quality circle or employee involvement type } \\
\text { programs are implemented in the childcare centre. }\end{array}$ & 3.94 & .730 \\
\hline $\begin{array}{l}\text { Amount of feedback provided to employees on their quality } \\
\text { performance. }\end{array}$ & ty 3.92 & .772 \\
\hline Quality awareness building among employees is ongoing. & 3.94 & .754 \\
\hline Average of Quality Assurance & 3.9446 & .57259 \\
\hline
\end{tabular}

\subsubsection{Mean and Standard Deviation of Physical Facilities}

Table 17 shows mean and standard deviation of the independent variable "Physical Facilities". The most dominant factor in measuring Physical Facilities value is the item "Employee of childcare centre are well dresses and appear neat." which have the equal mean value of 4.26. Besides that, the item of "The childcare centre have up-to-date equipment." has the lowest mean value which is 3.99. Average of Physical Facilities has mean value of 4.09.
Table 17. Mean and Standard Deviation of Physical Facilities - Overall $(\mathrm{N}=379)$

\begin{tabular}{|c|c|c|}
\hline Items & Mean & $\begin{array}{l}\text { Standard } \\
\text { Deviation }\end{array}$ \\
\hline The childcare centre have up-to-date equipment. & 3.99 & .816 \\
\hline $\begin{array}{l}\text { The childcare centre physical facilities are visually } \\
\text { appealing. }\end{array}$ & 4.01 & .777 \\
\hline $\begin{array}{l}\text { Employee of childcare centre are well dresses and appear } \\
\text { neat. }\end{array}$ & 4.26 & .746 \\
\hline $\begin{array}{l}\text { The appearance of the physical facilities of childcare is in } \\
\text { keeping with the types of service provided. }\end{array}$ & 4.09 & .736 \\
\hline Average of Physical Facilities & 4.09 & .620 \\
\hline
\end{tabular}

\subsubsection{Mean and Standard Deviation of Employee Commitment}

Table 18 shows mean and standard deviation of independent variable "Employee Commitment". The most dominant factor in measuring Employee Commitment value is the item "I am willing to put a great deal of effort beyond that normally expected in order to help childcare centre be successful." which have the equal mean value of 4.16. Besides that, the item of "I find that my value and childcare centre values are very similar." has the lowest mean value which is 3.74. Average of Employee Commitment has mean value of 3.98 .

Table 18. Mean and Standard Deviation of Employee Commitment - Overall $(\mathrm{N}=379)$

\begin{tabular}{lcc|}
\hline $\begin{array}{l}\text { Items } \\
\begin{array}{l}\text { I am willing to put a great deal of effort beyond that } \\
\text { normally expected in order to help childcare centre be } \\
\text { successful. }\end{array}\end{array}$ & $\begin{array}{c}\text { Standard } \\
\text { Deviation }\end{array}$ \\
$\begin{array}{l}\text { I would accept almost any type of job assignment in } \\
\text { order to keep working for childcare centre. }\end{array}$ & 4.16 & .764 \\
$\begin{array}{l}\text { I find that my value and childcare centre values are } \\
\text { very similar. }\end{array}$ & 3.74 & .827 \\
$\begin{array}{l}\text { I am proud to tell others that I am part of this childcare } \\
\text { centre. }\end{array}$ & 4.04 & .807 \\
$\begin{array}{l}\text { Childcare centre really inspires the very best in me in } \\
\text { the way of job performance. }\end{array}$ & 4.01 & .754 \\
$\begin{array}{l}\text { I am extremely glad that I choose childcare centre to } \\
\text { work for over others I was considering at the time I }\end{array}$ & 3.96 & .807 \\
joined. & & .832 \\
$\begin{array}{l}\text { For me, this is the best of all possible childcare centre } \\
\text { for which to work. }\end{array}$ & 3.92 & .616 \\
\begin{tabular}{l} 
Average of Employee Commitment \\
\hline
\end{tabular} & 3.98 &
\end{tabular}

\subsubsection{Mean and Standard Deviation of Communication}

Table 19 shows mean and standard deviation of independent variable "Communication". The most dominant factor in measuring Communication value is the item "I have been initiate and maintain respectful communication with each child." which have the equal mean value of 4.27 . Besides that, the item of "I have received the written information about the childcare centre's management to staff." 
has the lowest mean value which is 3.82. Average of Communication has mean value of 4.07.

Table 19. Mean and Standard Deviation of Communication - Overall $(\mathrm{N}=379)$

\begin{tabular}{|c|c|c|}
\hline Items & Mean & $\begin{array}{l}\text { Standard } \\
\text { Deviation }\end{array}$ \\
\hline $\begin{array}{l}\text { I have been interact with each child in a warm and friendly } \\
\text { way. }\end{array}$ & 4.25 & .711 \\
\hline $\begin{array}{l}\text { I have been initiate and maintain respectful communication } \\
\text { with each child. }\end{array}$ & 4.27 & .734 \\
\hline $\begin{array}{l}\text { I have been communicate effectively to promote respect and } \\
\text { professional teamwork. }\end{array}$ & 4.19 & .693 \\
\hline $\begin{array}{l}\text { I have been communicate with families effectively to } \\
\text { exchange information about each child and centre. }\end{array}$ & 4.04 & .806 \\
\hline $\begin{array}{l}\text { I have the written information about the childcare centre's } \\
\text { management which is readily available to families. }\end{array}$ & 3.86 & .838 \\
\hline $\begin{array}{l}\text { I have received the written information about the childcare } \\
\text { centre's management to staff. }\end{array}$ & 3.82 & .837 \\
\hline Average of Communication & 4.07 & .601 \\
\hline
\end{tabular}

\subsubsection{Mean and Standard Deviation of Employee Competencies}

Table 20 shows mean and standard deviation of the independent variable "Employee Competencies". The most dominant factor in measuring Employee Competencies value is the item "I am able to maintain energy level, motivating myself to perform, maintain positive attitude and responding appropriately to criticism in childcare centre" which have the equal mean value of 4.06 . Besides that, the item of "I am able to manage several task at once, being able to set priorities and allocate time efficiently in order to meet deadlines in childcare centre" has the lowest mean value which is 3.98. Average of Employee Competencies has mean value of 4.03 .

Table 20. Mean and Standard Deviation of Employee Competencies - Overall $(\mathrm{N}=379)$

\begin{tabular}{llc}
\hline Items & Mean & $\begin{array}{c}\text { Standard } \\
\text { Deviation }\end{array}$ \\
\hline $\begin{array}{l}\text { I have the knowledge from every day experiences and formal } \\
\text { education experience about childcare. }\end{array}$ & .761 \\
$\begin{array}{l}\text { I am able to manage several task at once, being able to set } \\
\text { priorities and allocate time efficiently in order to meet }\end{array}$ & .98 \\
deadlines in childcare centre. & .770 \\
$\begin{array}{l}\text { I am able to maintain energy level, motivating myself to } \\
\text { perform, maintain positive attitude and responding }\end{array}$ & \\
appropriately to criticism in childcare centre. & .734 \\
$\begin{array}{l}\text { I am able to identify, prioritizing and solving problem in } 4.04 \\
\text { childcare centre. }\end{array}$ & .755 \\
\hline $\begin{array}{l}\text { Average of Employee Competencies } \\
4.03\end{array}$ & .639
\end{tabular}

\subsection{Statistical Analysis Inference}

In this study, inference statistical analysis used to analyze the findings through test method like Person's Correlation and regression analysis to test the hypotheses in order to achieve the research objectives. The aim of using Pearson Correlation
Analysis is to gain view of the relationship between quality assurance, physical facilities, employee commitment, employee competencies and communication. On the other hand, Multiple Regression Analysis was used to investigate the relationship of direct hypotheses in the study.

\subsubsection{Pearson Correlation Analysis}

To be precise, a correlation of \pm 0.5 implies a significant relationship. In addition according to [18] mentioned that if correlation can be categories with small, medium and strong if the correlation is between 0.1 to $0.29,0.3$ to 0.49 and 0.50 to 1.00 respectively. Table 21 below shows the result of Pearson Correlation Analysis.

Table 21. Result of Pearson Correlation Analysis

\begin{tabular}{|c|c|c|c|c|c|}
\hline & \multicolumn{4}{|c|}{ Correlations } & \multirow{2}{*}{$\begin{array}{c}\text { Employee } \\
\text { Competencies }\end{array}$} \\
\hline & $\begin{array}{c}\text { Quality } \\
\text { Assurance }\end{array}$ & $\begin{array}{l}\text { Physical } \\
\text { Facilities }\end{array}$ & $\begin{array}{c}\text { Employee } \\
\text { Commitment }\end{array}$ & Communication & \\
\hline $\begin{array}{l}\text { Quality } \\
\text { Assurance }\end{array}$ & 1 & $.645^{* *}$ & $.629^{* *}$ & $.555^{* *}$ & $.562^{* *}$ \\
\hline $\begin{array}{l}\text { Physical } \\
\text { Facilities }\end{array}$ & $.645^{* *}$ & 1 & $.684^{* *}$ & $.596^{* 8}$ & $.608^{* *}$ \\
\hline $\begin{array}{c}\text { Employee } \\
\text { Commitment }\end{array}$ & $.629^{* *}$ & $.684^{* *}$ & 1 & $.753^{* *}$ & $.725^{* *}$ \\
\hline Communication & $.555^{* *}$ & $.596^{* *}$ & $.753^{* *}$ & 1 & $.781^{* *}$ \\
\hline $\begin{array}{c}\text { Employee } \\
\text { Competencies }\end{array}$ & $.562^{* *}$ & $.608^{* *}$ & $.725^{* *}$ & $.781^{* *}$ & 1 \\
\hline
\end{tabular}

Based on the correlation result as table 21 above, all independent variable physical facilities, employee commitment, communication and employee competencies illustrate the value of $r$ is more than 0.5 in which the physical facilities of the variable $r$ was 0.645 , and employee commitment, communication and employee competencies with variable $\mathrm{r}$ were $0.629,0.555,0.562$ respectively. All the independent variable shows strong correlation with quality assurance.

\subsubsection{Multiple Regression Analysis}

Multiple regression analysis has been used to identify the connection for more than two variables in the study. The result of multiple regression analysis can decide whether which independent variable more significant toward quality assurance. Tables below shows the result of multiple regression test.

Table 22. Model Summary

Model Summary

\begin{tabular}{lrrrr}
\hline \multicolumn{4}{c}{ Model Summary } \\
Model & R & R Square & Adjusted R Square & $\begin{array}{c}\text { Std. Error of the } \\
\text { Estimate }\end{array}$ \\
\hline 1 & $.701^{\mathrm{a}}$ & .492 & .486 & .41046 \\
\hline
\end{tabular}


The coefficient of determination (R2) can be explained as outcome from regression and predict the relations with variable. The purpose of R2 has explained the changes of independent variable such as physical facilities, employee commitment, communication, and employee competencies. Table 22 shows the model of summary of multiple regression analysis. The analysis shows that the value of adjusted R2 was 0.486 . This proved that physical facilities, employee commitment, communication and employee competencies were elaborated $48.6 \%$ of changes in the quality assurance as tested in the model. Thus, it proven that it had $48.6 \%$ of influence to quality assurance.

Table 23. Regression Analysis Coefficientsa

\begin{tabular}{|c|c|c|c|c|c|c|}
\hline & \multirow{2}{*}{ Model } & \multicolumn{2}{|c|}{$\begin{array}{l}\text { Unstandardized } \\
\text { Coefficients }\end{array}$} & \multirow{2}{*}{$\begin{array}{c}\begin{array}{c}\text { Standardized } \\
\text { Coefficients }\end{array} \\
\text { Beta } \\
\end{array}$} & \multirow{2}{*}{$\mathbf{t}$} & \multirow{2}{*}{ Sig. } \\
\hline & & B & $\begin{array}{c}\text { Std. } \\
\text { Error }\end{array}$ & & & \\
\hline \multirow{5}{*}{1} & (Constant) & 0.99 & 0.161 & & 6.164 & 0 \\
\hline & $\begin{array}{l}\text { Physical } \\
\text { Facilities }\end{array}$ & 0.344 & 0.048 & 0.372 & 7.166 & 0 \\
\hline & $\begin{array}{c}\text { Employee } \\
\text { Commitment }\end{array}$ & 0.233 & 0.06 & 0.251 & 3.897 & 0 \\
\hline & Communication & 0.061 & 0.062 & 0.064 & 0.973 & 0.331 \\
\hline & $\begin{array}{c}\text { Employee } \\
\text { Competencies }\end{array}$ & 0.093 & 0.057 & 0.103 & 1.631 & 0.104 \\
\hline
\end{tabular}

a. Dependent Variable: Quality Assurance

Table 22 shows the one-way ANOVA while Table 23 shows the result of Regression Analysis of Coefficient tests. The overall results of the multiple regression analysis showed that all independent variable have a relationship with the dependent variable when $\mathrm{F}=90.399$ and $\mathrm{p}=0.000$. The result of this test also indicated that all independent variable had positive beta coefficient value as physical facilities, employee commitment, communication and employee competencies have 0.372, 0.251, 0.064 and 0.103 respectively.

From the result, it also can be identified that not all independent variable showed a significant relationship as the significant level, $\mathrm{p}$ value is in between 0.01 and 0.05 . This is supported by physical facilities $(\mathrm{p}=0.000)$, employee commitment $(\mathrm{p}=0.000)$, communication $(\mathrm{p}=0.331)$ and employee competencies (0.104).

\subsection{Summary of Hypotheses Testing}

The result summary of hypothesis testing shown in the Table 24 below.
Table 24. Summary of Hypothesis Testing

\begin{tabular}{|l|l|l|}
\hline & DESCRIPTION OF HYPOTHESIS & RESULT \\
\hline H1 & $\begin{array}{l}\text { There is a significant relationship between Physical } \\
\text { Facilities and Quality Assurance among childcare } \\
\text { employees in Selangor. }\end{array}$ & ACCEPTED \\
\hline H2 & $\begin{array}{l}\text { There is a significant relationship between Employee } \\
\text { Commitment and Quality Assurance among childcare } \\
\text { employees in Selangor. }\end{array}$ & ACCEPTED \\
\hline H3 & $\begin{array}{l}\text { There is a significant relationship between } \\
\text { Communication and Quality Assurance among childcare } \\
\text { employees in Selangor. }\end{array}$ & ACCEPTED \\
\hline H4 & $\begin{array}{l}\text { There is a significant relationship between Employee } \\
\text { Competencies and Quality Assurance among childcare } \\
\text { employees in Selangor. }\end{array}$ & ACCEPTED \\
\hline
\end{tabular}

\section{Conclusion}

The main objective of this research is to identify the factors that influence quality assurance among childcare employees in Selangor, Malaysia. The findings of current research proven that there are positive relationships on factors influence quality assurance. The overall results of the multiple regression analysis showed that all independent variables have relationships with the dependent variable at $\mathrm{F}=90.399$ and $\mathrm{p}=0.000$. The result of this test also indicated that all independent variables have positive beta coefficient value as physical facilities, employee commitment, communication and employee competencies at $0.372,0.251,0.064$ and 0.103 respectively.

From the result, it also can be identified that not all independent variables showed significant relationships at the significant level, $\mathrm{p}$ value is in between 0.01 and 0.05 . This is supported by physical facilities $(\mathrm{p}=0.000)$, employee commitment $(\mathrm{p}=0.000)$, communication $(\mathrm{p}=0.331)$ and employee competencies (0.104). Precisely, this research identified the relationship of physical facilities, employee commitment, employee competencies, communication and quality assurance among childcare employee in Selangor. In fact, the existing study was developed due to limited studies or research in relevant literature related to relationship of factors influence quality assurance in childcare industry. From the findings, the hypothesis framework was proven positively significant. Quality assurance are important to contribute continuous improvement and quality in organization. Some of the measurement scale provided to measure quality assurance in childcare such as [36]. To conclude, the better of physical facilities, employee commitment, employee competencies and communication, the higher the quality assurance of childcare. Therefore, the childcare provider or policy maker should implement or develop a better 
quality assurance model in order to improve the quality of childcare through better facilities in the centre, training and education level of the employee to improve the competency level, improve communication between employer and employee to lead better satisfaction and higher employee commitment. All this will helps to improve the quality of childcare through the implementation of quality assurance in childcare centre.

Lastly, future research can include childcare employee in all the state in Malaysia or other country. Besides, future research can be conducted by having similar ethnic group of respondents to measure whether any difference in the result. In addition, future studies can be made in qualitative method to have a better understanding of quality assurance based on the depth of interview with respondent. Also, future research can include or explore more variables which can contribute to the development of quality assurance level. Besides, add mediator or moderator to furnish the research framework towards a better model.

\section{Acknowledgment:}

*This research was supported by Ministry of Higher Education (MoHE) of Malaysia through Fundamental Research Grant Scheme (FRGS/1/2017/SS03/UUM/02/14).

\section{References:}

[1] Retrieved June 5, 2021, from http://www.themalaymailonline.com/malaysia/a rticle/bn-claims-success-in-boosting-womensincome-and-positions

[2] Ming, Y. T. W., \& Choy, C. S. (2014). Towards strengthening the development of women entrepreneurship in Malaysia. Gender in Management: An International Journal, 29(7), 432-453. https://doi.org/10.1108/GM-10-20130122

[3] Keçetep, İ., \& Özkan, İ. (2014). Quality Assurance in the European Higher Education Area. Procedia - Social and Behavioral Sciences, $\quad 141, \quad 660-664$. https://doi.org/10.1016/j.sbspro.2014.05.115

[4] Nicholson, K. (2011). Quality Assurance in Higher Education: A Review of the Literature. Council of Ontario Universities Degree Level Expectations Project, 1-15. https://doi.org/10.18870/hlrc.v5i4.257

[5] Abdghani, N. H., Nikmat, N. K., Sulaiman, Y., (2019). Export performance: The role of product quality and market orientation. WSEAS
Transactions on Business and Economics 16 (25), 215-225.

[6] Sulaiman, Y., Rahman, M. A., Mat, N. K. N., (2020). Enhancing student active learning in consumer behaviour class using 5E learning cycle: A conceptual paper. WSEAS Transactions on Environment and Development 16 (53), 520529.

[7] Sulaiman, Y., Bakar, N. A. A., Ismail, M. Y. S., Mat, N. K. N., Musa, R., (2017). The function of marketing mix and consumer preferences on healthy food consumption among UUM students. International Journal of Economic Research 14 (19), 103-122.

[8]Sulaiman, Y., Kan, W. P. E., Salimon, M. B. (2020). Purchase Intention towards Organic Food among Undergraduate Students. WSEAS Transactions on Environment and Development, 16, 734-743.

[9] Beynon, J. (1997). Physical Facilities for education: What planners need to know. Fundamental of Education Planning - 57.

[10] Ries, A. V., Yan, A. F., \& Voorhees, C. C. (2011). The neighbourhood recreational environment and physical activity among urban youth: An examination of public and private recreational facilities. Journal of Community Health, 36(4), 640-649. https://doi.org/10.1007/s10900-010-9355-1

[11] Sulaiman, Y., Masri, M., Yusr, M. M., Mustafa, S. A., \& Salim, N. (2017). The relationship between marketing mix and consumer preference in supplement product usage. International Journal of Economic Research 14 (19), 381-393.

[12] Mat, N. K. N., Sulaiman, Y., Ghani, N. H. A., Mohamad, N., (2018). Halal Consumption Pattern Determinants: Sequential Mediating effects of Muslim Lifestyle, Trust and Risk Perception. Journal of Social Sciences Research 2018 (Special Issue 6), 444-453.

[13] Mowday, R. T. ., Porter, L. W. ., \& Steers, R. M. (1983). Employee-Organization linkages: The psychology of commitment, absenteeism, and turnover. American Journal of Society (Vol. 88). https://doi.org/10.2307/2068333

[14] Locke, E. A., Latham, G. P., \& Erez, M. (1988). The Determinants of Goal Commitment. Academy of Management Review, 13(1), 23-39. https://doi.org/10.5465/AMR.1988.4306771

[15] Blau, G. J. (1986). Job involvement and organizational commitment as interactive predictors of tardiness and absenteeism. Journal of Management, 12, 577-584. 
[16] Allen, N. J., \& Meyer, J. P. (1990). The measurement and antecedents of affective, continuance and normative commitment to the organization. Journal of Occupational $\begin{array}{llll}\text { Psychology, } & 63 & (1), & 1-18 .\end{array}$ https://doi.org/10.1111/j.20448325.1990.tb00506.x

[17] Iqbal, A., Tufail, M. S., \& Lodhi, R. N. (2015). Employee Loyalty and Organizational Commitment in Pakistani Organizations. Global Journal of Human Resource Management, 3 (1), $1-11$.

[18] Sulaiman, Y., Othamn, A. R., Perumal, S., Hussain, Z. (2013). Escalating the Employee Job Satisfaction through Internal Market Orientation: A Childcare Centre Perspective. Jurnal Teknologi (sciences and Engineering) 64(2), 133-138.

[19] Sulaiman, Y., Jauhari, N. (2021). The Factors Influencing Mobile Banking Usage among University Staff. WSEAS Transactions on Business and Economics 18, pp. 179-189.

[20] Cartier, F. A., \& Hanvood, K. A. (1953). Definition of communication. Journal of Communication, 3(2), 71-75. https://doi.org/10.1111/j.14602466.1953.tb01076.x

[21] Watson Wyatt White Paper. (2008-2009). Driving business results through continuous engagement. Retrieved from http://www.watsonwyatt.com/research/pdfs/200 8-US-0232.pdf

[22] Cardy, R. L., \& Selvarajan, T. T. (2006). Competencies: Alternative frameworks for competitive advantage. Business Horizons, 49(3), 235-245. https://doi.org/10.1016/j.bushor.2005.09.004

[23] Boyatzis, R. E. (2009). Competencies as a behavioral approach to emotional intelligence. Journal of Management Development, 28(9), 749-770. https://doi.org/10.1108/02621710910987647

[24] Ley, T., Albert, D.: "Kompetenzmanagement als formalisierbare Abbildung von Wissen und Handeln für das Personalwesen [Competence management - formalizing knowledge and action for human resource management] "; Wirtschaftspsychologie, 5, 3 (2003), 86-93.

[25] Drejer, A. (2000). Organizational learning and competence development., The Learning Organization, 7(4), 206-220

[26] Hoffmann, T. (1999). The meanings of competency. Journal of European Industrial Training, 23(6), 275-286. https://doi.org/10.1108/03090599910284650

[27]Roscoe, J.T. (1975) Fundamental Research Statistics for the Behavioural Sciences, 2nd edition. New York: Holt Rinehart \& Winston.

[28] Krejcie, R.V. \& Morgan, D.W. (1970). Determining sample size for research activities. Educational \& Psychological Measurement, 30, 607-610

[29] Sekaran, U., \& Bougie, R. (2016). Research Methods for Business: A Skill Building.

[30] Andale, S. (2017). Kaiser-Meyer-Olkin (KMO) Test for Sampling Adequacy.

[31] Armitage, E. G., Godzien, J., AlonsoHerranz, V., López-Gonzálvez, Á., \& Barbas, C. (2015). Missing value imputation strategies for metabolomics data. Electrophoresis, 36(24), 3050-3060.

https://doi.org/10.1002/elps.201500352

[32] Cheema, J. R. (2014). A review of missing data handling methods in education research. Review of Educational Research, 0034654314532697. https://doi.org/10.3102/0034654314532697

[33] Ghasemi, A., \& Zahediasl, S. (2012). Normality tests for statistical analysis: A guide for non-statisticians. International Journal of Endocrinology and Metabolism, 10(2), 486489. https://doi.org/10.5812/ijem.3505

[34] Fryrear, A. (2015). What's a Good Survey Response Rate? Retrieved from https://www.surveygizmo.com/surveyblog/survey-response-rates/

[35] Ford, C. (2015). Understanding Q-Q Plots University of Virginia Library Research Data Services + Sciences

[36] Rowe, K. (2006). The measurement of composite variables from multiple indicators: Applications in Quality Assurance and Accreditation Systems-Childcare. Acer, (August), 1-16. Retrieved from http://ncac.acecqa.gov.au/reports/reportdocuments/composite_variables.pdf

[37] Sulaiman, Y., Jamil, N. A. M., Othman, A. R., \& Musa, R. (2020). The Influence of Green marketing, Syariah Compliance, Customer's Environmental Awareness and Customer's Satisfaction towards Muslim Consumer Purchasing Behaviour in Kedah. WSEAS Transactions on Business and Economics, 17, 194-204.

[38] Sulaiman, Y., Perumal, S., Ghani, N.H.A., Ismail, M. Y. S, \& Musa, R. (2017). A 
conceptual paper on safety and quality assurance model in Malaysian child care centres. International Journal of Economic Research, 14 (19), 333-340.

[39] Sulaiman, Y., \& Muhamad Kashfi, N. Z. A. (2019). The Factors Influence Job Satisfaction among Childcare Employees: A Study in Kedah. Journal of Advanced Research in Dynamical and Control Systems, 11 (5), 527-535.

[40] Sulaiman, Y., \& Lie, N. K. (2019). The Factors Influence Quality Assurance Level among Childcare Employees in Selangor. Journal of Advanced Research in Dynamical and Control Systems, 11 (5), 564-577.

[41] Sulaiman, Y., Basri, N. A. M (2019). The Factors Influence Safety Assurance Level among Child Care Centres in Perak. Journal of Advanced Research in Dynamical and Control Systems, 11 (5), 582-590.

[42] Kim-Soon, N., Chin, L. H., \& Ahmad, A. R. (2017). Quality assurance practices of small size food manufacturing companies in Malaysia. Advanced Science Letters, 23(1), 382-385.

https://doi.org/10.1166/asl.2017.7192

[43] Othman, B., Shaarani, S. M., \& Bahron, A. (2016). Evaluation of knowledge, halal quality assurance practices and commitment among food industries in Malaysia. British Food Journal, 118(8), 2033-2052. https://doi.org/10.1108/BFJ-12-2015-0496

Contribution of Individual Authors to the Creation of a Scientific Article (Ghostwriting Policy)

Yaty Sulaiman was responsible for conceptualization, funding acquisition, project administration, resources, supervision, review and editing of the article.

$\mathrm{Ng} \mathrm{Kel} \mathrm{Lie} \mathrm{was} \mathrm{responsible} \mathrm{for} \mathrm{data} \mathrm{curation,} \mathrm{formal}$ analysis, methodology, validation, and writing the original draft.

\section{Sources of Funding for Research Presented in a Scientific Article or Scientific Article Itself \\ *This research was supported by Ministry of Higher Education (MoHE) of Malaysia through Fundamental Research Grant Scheme (FRGS/1/2017/SS03/UUM/02/14).}

\section{Creative Commons Attribution License 4.0 (Attribution 4.0 International, CC BY 4.0)}

This article is published under the terms of the Creative Commons Attribution License 4.0

https://creativecommons.org/licenses/by/4.0/deed.en US 